\title{
SOME ASPECTS OF WATER QUALITY CHARACTERISTICS IN SMALL SHALLOW TROPICAL MAN-MADE RESERVOIRS IN KENYA
}

\author{
Mwaura, F. \\ Department of Geography and Environmental Studies, University of Nairobi, \\ P.O. Box 30197 Nairobi GPO 00100, Kenya
}

\begin{abstract}
The water quality in eight small reservoirs $\left(0.065-0.249 \mathrm{~km}^{2}\right)$ in both the rugged escarpment landscape above the rift valley floor and the stepped plateau above them were studied between 1998 and 2000. Water transparency was measured using a 20cm Secchi visibility disk. Total dissolved solids (TDS) and electrical conductivity (specific conductance) with temperature compensation at $25^{\circ} \mathrm{C}$ were recorded in situ from a portable Jenway probe model 4075. Water $\mathrm{pH}$, dissolved oxygen $(D O)$, percentage oxygen saturation (POS) were recorded on site from a portable WTW probe model ProfiLine Oxi 197/197-S. The overall range of mean water $p H$ was $7.0-8.4$ while the overall range of mean TDS was 29-82 mg/l. The TDS was slightly higher in the plateau reservoirs. The overall range of specific conductance was 37-101 $\mu \mathrm{S} / \mathrm{cm}$. The range of TDS and specific conductance in the reservoirs was quite low compared to other reservoirs in Kenya. The mean range of dissolved oxygen and percentage oxygen saturation was 2.0-7.2 $\mathrm{mg} / \mathrm{l}, 23.4 .2-33.6 \%$, respectively. The level of dissolved oxygen was quite low in most reservoirs with dry season hypolimnial oxygen deficits in some sites and higher dissolved oxygen content in the more transparent reservoirs. The summary results showed a clear difference in water quality between the plateau and escarpment reservoirs in the study area. The water quality in the reservoirs was found to be suitable for domestic and livestock utilization. However, additional water quality parameters are required to confirm this conclusion. The reservoirs were found to possess a good potential for multipurpose development.
\end{abstract}

KEY WORDS: Water pH, TDS, dissolved oxygen, reservoir utilization

\section{INTRODUCTION}

According to WWF (1999), reservoirs became popular for water supply in the Mediterranean region during Roman times and were first introduced in Western Europe during the Late Middle Ages. During the $19^{\text {th }}$ Century, many small reservoirs were created in Britain and the United States for water supply, recreation, fisheries and aquaculture (WWF, 1999). Thereafter, the era of large dams started in the early 1900s and increased swiftly after 1950 during which, reservoirs were viewed as status symbols reflecting a country's progress and prestige (WWF, 1999). According to ICOLD (1998), over 300 new dams were constructed in the world each year between the 1950s and 1980s. Although this number dropped to about 250 dams a year in the 1990s, the rate has continued to increase particularly within the developing countries. By the late nineties the total area occupied by reservoirs worldwide was about $384000 \mathrm{~km}^{2}$ or roughly the size of Zimbabwe (WWF 1999).

Reservoirs are usually created for several purposes. According to ICOLD (1998), $48 \%$ of the world reservoirs are for irrigation, and $20 \%$ for hydropower generation. The rest are mainly for flood control, domestic and industrial water supply, and recreation. In Southern Africa, over 500 manmade lakes have been constructed to fulfill a multipurpose role of water supply, recreation, fisheries, power supplies and receptacles for treated municipal wastewater (Thornton, 1987a). In the USA alone, more than 2500 reservoirs are used for recreation and tourism. The use of reservoirs by birds, 
wildlife, and fish is nowadays known to attract a lot of ornithologists, naturalists, hunters, and anglers (Patten 1998). According to Mwaura (2004), there are probably between 5 000 to 14345 small reservoirs in the semi-humid and savanna areas of Kenya only occupy approximately $3.9 \%$ and $8 \%$, respectively.

Water quality in reservoirs is an important aspect of water resources management. It is a key catalyst for development and conservation because it determines the spatiotemporal dynamics of aquatic organisms and drives various water uses in aquatic ecosystems including reservoirs. The broad aspect of water quality can be visualized in terms of the physical and chemical properties within which several elements of water quality can be identified. The parameters of water quality are chemically classified into cationic, ionic, inorganic, and organic forms. Some general water quality parameters like transparency, temperature, $\mathrm{pH}$ and conductivity usually serve as general indicators of water quality across the board.

Reservoir water is rarely pure since it contains different kinds of dissolved and particulate matter including gases and solids. The entry of most ions into the aquatic ecosystems is particulate matter which is reflected by the levels of water transparency. The transparency of a water column, which is determined by the amount of light penetration, is determined by a Secchi disk depth. This is the depth in which a white disk of a certain size is no longer visible to the human eye when lowered slowly into the water. This depth is often influenced by the amount of algae as well as other particulate and dissolved substances. Secchi disk depth is, therefore, a good indicator of environmental health and ecological productivity. Water bodies with Secchi depths of less than $1 \mathrm{~m}$ are usually heavily loaded with suspended sediments and nutrients.

The general state of reservoir water quality can be estimated by $\mathrm{pH}$ which is a simple measure of acidity or alkalinity with a scale of 1 to 14. Tilman et al. (1982) have referred to $\mathrm{pH}$ as the master variable in the chemistry of aquatic systems. The $\mathrm{pH}$ range below 7 indicates acidic conditions while that above 7 indicates alkalinity. Most water systems have $\mathrm{pH}$ of 6 to 9 but saline soda lakes can have values as high as 10. In most places, the $\mathrm{pH}$ of closed or endorheic water bodies are very different from that of the open or exhorheic ones. However, some aquatic ecosystems can display variability in their $\mathrm{pH}$ characteristics in response to alternate wet and dry conditions particularly within arid and semi arid areas (Taub, 1996). According to Moehl and Davies (1993), typical, water pH in reservoirs ranges from 5 to 10 but it can fluctuate upwards or downwards as a result of changes in photosynthetic intensity.
According to Goldman and Horne (1983), low water $\mathrm{pH}$ of between 4 and 5 can influence biodiversity by favouring or discouraging the presence of certain lifeforms.

Apart from water $\mathrm{pH}$, the state of water quality in reservoirs can be determined by the level of total dissolved solids (TDS) and electrical conductivity. The electrical conductivity (specific conductance) of water is an expression of its capacity to conduct a current and is related to the concentration of free ions and to water temperature (Goldman and Horne 1983). Conductivity provides a quick, convenient estimate of the ionic content and thus the quality of water, as well as a quick check on water suspected of having received ionic pollutants (Goldman and Horne (1983).

One very dynamic attribute of reservoirs water quality is dissolved oxygen (DO) which changes rapidly under the influence of different environmental factors such as temperature, elevation and the chemical nature of bottom sediments. Some studies have, for example shown that large amounts of oxygen are dissolved in water when atmospheric temperature and elevation are relatively low (Meaden and Kapetsky 1991, Moehl and Davies 1993). The amount of oxygen in water manifests significant spatio-temporal variation. Sometimes reservoirs can experience seasonal hypolimnial oxygen deficit which according to Thienemann (1928), is an indicator of productive systems. Recent findings have demonstrated more clearly how the level of dissolved oxygen controls certain biogeochemical processes like the nitrogen cycle which ultimately regulate the level of productivity in aquatic ecosystems (Howard-Williams et al. 1989). Templer et al. (1998), for example have shown how both nitrification and denitrification are closely regulated by aerobic and anaerobic conditions in aquatic ecosystems. Ultimately, the concentration of dissolved oxygen exerts a very strong control on the distribution of aerobic organisms. The average level of oxygen for most aerobic life in water is $8 \mathrm{mgO} / \mathrm{l}$, but this is nowadays very hard to maintain due to the increasing problems of pollution and eutrophication. In recent years, biomanipulation is offering some new and promising opportunities of improving aeration through active water management.

The broad aim of this study was to assess the spatio-temporal variability of water quality in small reservoirs in the high altitude central part of the Eastern Rift Valley in Kenya. The specific objectives were twofold. Firstly was to establish the spatio-temporal variability in water transparency, water $\mathrm{pH}$, total dissolved solids (TDS), electrical conductivity, dissolved oxygen, oxygen saturation and oxidation reduction or redox. potential Secondly was to establish the implication of water quality on reservoir utilization at the local level. 


\section{STUDYAREA}

The eight reservoirs selected for study were located 100 $200 \mathrm{~km}$ Northwest of Nairobi in the Central and Rift Valley Provinces (Figure 1). The study area was mainly under ecological zones III and IV (Pratt et al. 1966) which provide a great contrast in terms of relief, climate, vegetation and landuse. The reservoirs were fed primarily by surface drainage through river flow, but Kiongo Reservoir was fed almost entirely by diffuse surface runoff and underground in-seepage. Both Muruaki and Kahuru

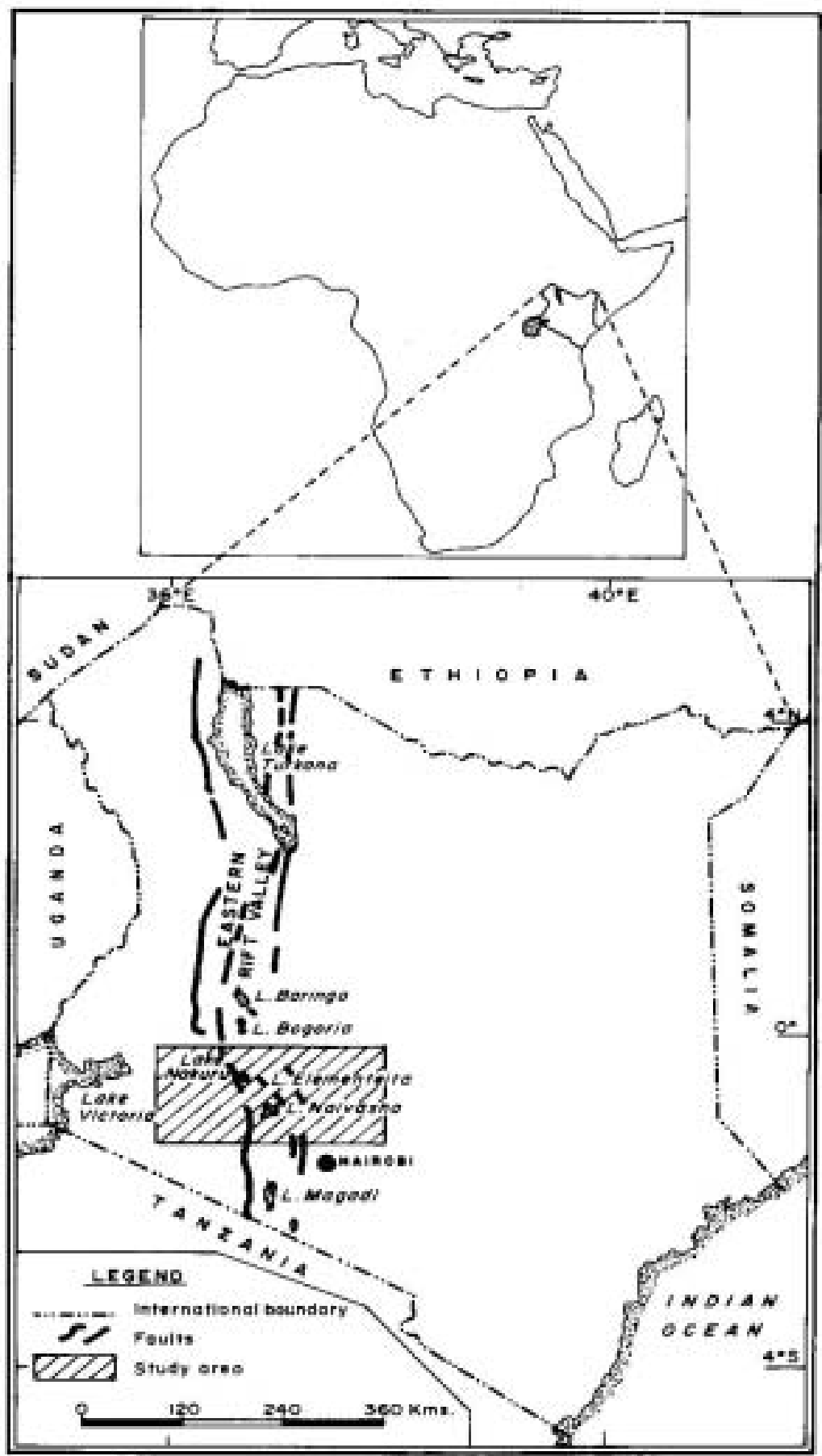

Figure 1: The location of the study area (Mwaura 2004) 
Reservoirs were hydrologically distinct because the former overflows into the latter during periods of high water levels. These reservoirs were good in the assessment ofupstream-downstream water quality transformations between reservoirs.

The eight study reservoirs were from the two major physiographic zones in the region, namely the highland plateaus and rift escarpments. Four reservoirs were selected from the plateaus namely Muruaki, Kahuru, Murungaru and Kanguo while the rest namely Gathanje, Kiongo, Rutara and Gathambara were located in the rugged escarpment below the plateau. The plateau reservoirs were characterized by flat open grassland landscape while the escarpment reservoirs had rugged landscape with higher forest cover. Table 1 shows the geomorphometric characteristics of the study reservoirs.

The study area can be divided into two specific physiographic zones namely; the Kinangop-Ol Kalou Plateau and the Aberdares and Mau Escarpments. The Kinangop and Olkalou area is strictly not a true plateau but a broad "Stepped Plateau" whose elevation range is approximately $2380-2440 \mathrm{~m}$. It is underlain by soft pyroclastic rocks, which according to Thompson (1962) are probably of Kamasian age (lower Middle Pleistocene). The most common pyroclastic rocks are soft, light coloured tuffs, which occasionally form very thick deposits but powdery light grey pumiceous ash is common over much of the Kinangop area. The chemical analyses of rocks in the Kinangop area have shown that they are quite rich in $\mathrm{SiO}_{2}, \mathrm{Al}_{2} \mathrm{O}_{3}, \mathrm{FeO}, \mathrm{CaO}$ and $\mathrm{MgO}$ (Thompson, 1962), which is similar to the patterns in other African drainage basins (Martins and, 2002). The Mau escarpment on the other hand is composed of rocks with largely soft volcanic ashes and tuffs which are highly vulnerable to erosion due to their extremely soft nature.

Climate in the study area is cool and humid the rainfall pattern is predominantly bimodal. The long rains usually fall between April and June while short rains are experienced between October and November. Mean annual rainfall varies from $1200 \mathrm{~mm}$ around Nyahururu, Bahati and Subukia to $1100 \mathrm{~mm}$ in Kinangop, Ol Kalou and Ol Joro Orok and $1000 \mathrm{~mm}$ in Nakuru, Ndunduri and Upper Gilgil. Within the Rift Valley floor, the ultimate destination of rivers in the study area, mean annual

Table 1: The geographic and morphometric characteristics of the study reservoirs

\begin{tabular}{|l|l|c|c|c|c|c|}
\hline Reservoir & Location & Age (yrs.) & Area $\left(\mathrm{km}^{2}\right)$ & $\begin{array}{l}\text { Catchment } \\
\text { Area }\left(\mathrm{km}^{2}\right)\end{array}$ & $\begin{array}{l}\text { Estimated volume } \\
\left(10^{3} \mathrm{~m}^{3}\right)\end{array}$ & $Z_{\max }(\mathrm{m})$ \\
\hline Muruaki & $0^{\circ} 38^{\prime} \mathrm{S}, 36^{\circ} 33^{\prime} \mathrm{E}$ & 45 & 0.102 & 29.1 & 230 & 3.5 \\
\hline Kahuru & $0^{\circ} 37^{\prime} \mathrm{S}, 36^{\circ} 32^{\prime} \mathrm{E}$ & 46 & 0.088 & 31.4 & 240 & 4.5 \\
\hline Murungaru & $0^{\circ} 366^{\prime} \mathrm{S}, 36^{\circ} 30^{\prime} \mathrm{E}$ & 48 & 0.116 & 57.3 & 280 & 3.8 \\
\hline Kanguo & $0^{\circ} 12^{\prime} \mathrm{S}, 36^{\circ} 25^{\prime} \mathrm{E}$ & 45 & 0.114 & 14.1 & 240 & 2.2 \\
\hline Gathanje & $0^{\circ} 03^{\prime} \mathrm{S}, 36^{\circ} 19^{\prime} \mathrm{E}$ & 45 & 0.119 & 22.4 & 400 & 6 \\
\hline Kiongo & $0^{\circ} 10^{\prime} \mathrm{S}, 36^{\circ} 15^{\prime} \mathrm{E}$ & 48 & 0.249 & 0.05 & 580 & 3.3 \\
\hline Rutara & $0^{\circ} 17^{\prime} \mathrm{S}, 36^{\circ} 15^{\prime} \mathrm{E}$ & 46 & 0.072 & 1.50 & 230 & 3.6 \\
\hline Gathambara & $0^{\circ} 27^{\prime} \mathrm{S} ; 36^{\circ} 02^{\prime} \mathrm{E}$ & 40 & 0.065 & 50 & 50 & 1.5 \\
\hline
\end{tabular}

precipitation is quite low and unreliable, rarely exceeding $740 \mathrm{~mm}$.

The human population density in the study area is in the range of 100 to 200 persons per square kilometer (CBS, 2003). The population density at Gathanje and Kiongo Reservoirs was estimated at approximately 500 persons per square kilometer during the study because of upcoming market centres near the reservoirs. The average settlement density around the reservoirs was estimated in this study to 100 houses per square kilometer using aerial photography taken in the 1960s and 1970s. Landuse is predominantly small-scale agriculture and livestock husbandry. Agriculture constitutes some $85 \%$ of the landuse in the reservoir catchments. The major crops include maize (Zea mays), wheat (Triticum aestivum), barley (Hordeum vulgare), potatoes (Solanum tuberosum), onions (Allium cepa.), beans (Beta vulgaris), cabbages (Brassica oleracea) and peas (Pisum sativum) which require huge amounts of agro-chemicals. Both free ranging and paddock livestock are reared. 


\section{METHODS}

A total of twenty one sampling sites were selected for data collection within the eight study reservoirs and fieldwork undertaken in different months between 1998 and 2001. The sampling protocol was arranged in three main clusters according to the dominant seasons as shown below:

[1] The hot dry season in February and March when reservoirs are usually quite low and hydrologically isolated following the dry spell.

[2] The long rain season in May, June and July when reservoirs are usually full and discharging water downstream.

[3] The short rain season in September, October, and December when the reservoirs are expected to manifest moderate hydro-ecological conditions.

The aim of the study was to capture the seasonal profile but not to establish a month-to-month picture. The results presented here therefore reflect an average composite profile for the study period.

Water transparency was measured using a $20 \mathrm{~cm}$ Secchi visibility disk while water temperature, TDS and specific conductance with temperature compensation at $25^{\circ} \mathrm{C}$ were recorded in situ at vertical intervals from a portable Jenway digital readout probe model 4075. Similarly, water $\mathrm{pH}$, dissolved oxygen (DO), percentage oxygen saturation (POS) and oxidation reduction (redox) potential (ORP) were recorded on site from a portable WTW probe model ProfiLine Oxi 197/197-S. These parameters were taken at $50 \mathrm{~cm}$ intervals from surface to bottom in shallow ASUs and $1 \mathrm{~m}$ intervals in deep ASUs (Brower and Zar, 1977; Goldman and Horne 1983).

\section{RESULTS}

Table 2 gives a summary of mean monthly water $\mathrm{pH}$ in the reservoirs The overall water $\mathrm{pH}$ picture indicated fairly similar trends in $\mathrm{pH}$ in all the reservoirs. The results showed that the water $\mathrm{pH}$ ranged from 6.9 to 7.9 with most of the reservoirs having water $\mathrm{pH}$ above 7 except Gathanje and Rutara. The highest $\mathrm{pH}$ was found in Muruaki (7.9), Kanguo (7.7) and Kiongo (7.8). The highest $\mathrm{pH}$ was reached at the end of the dry season in February and also after the long rains in June and July. The high water $\mathrm{pH}$ in the reservoirs between January and May, probably due to the strong influence of evaporative concentration that occurred in the dry season due to the high ambient temperatures and also because the reservoirs were endorheic at that time of the year.
Thereafter, $\mathrm{pH}$ declined at the onset of the long rains but increased slightly in June and July probably as result of greater quantities of suspended, dissolved and organic matter following the long rains in April and May. Slightly higher wet season $\mathrm{pH}$ was only noted in Kanguo and Gathambara probably due to increased soil loss. During the second half of the year the weather conditions appeared to be fairly moderate and this probably maintained water $\mathrm{pH}$ close to 7 (Table 2).

Table 2: A summary of seasonal water $\mathrm{pH}$ in the reservoirs

\begin{tabular}{lllllllll}
\hline Reservoir & Feb & Mar & Jun & Jul & Sep & Oct & Dec & Mean \\
Muruaki & 8.08 & 7.39 & 8.13 & 7.9 & 7.5 & 7.7 & 7.8 & 7.9 \\
Kahuru & 7.12 & 7.63 & 7.5 & 7.13 & 7.2 & 7.4 & 6.8 & 7.2 \\
Murungaru & 8.61 & 7.52 & 8.33 & 7.7 & 7.12 & 7.6 & 6.63 & 7.6 \\
Kanguo & 7.47 & 7.72 & 7.68 & 8.91 & 7.4 & 7.38 & 6.86 & 7.7 \\
Gathanje & 7.07 & 7.56 & 7.91 & 7.41 & 7.1 & 7.78 & 6.21 & 7 \\
Kiongo & 8.72 & 7.77 & 7.53 & 8.23 & 7.5 & 8.14 & 6.41 & 7.8 \\
Rutara & 7.75 & 5.78 & 7.4 & 7.4 & 7.12 & 7.34 & 6.39 & 6.9 \\
Gathambara & 7.42 & 6.52 & 7.7 & 7.56 & 7.3 & 6.86 & 9.34 & 7.5 \\
Mean & 7.8 & 7.2 & 7.8 & 7.8 & 7.1 & 7.5 & 7.1 & - \\
\hline
\end{tabular}

The overall mean TDS for the reservoirs ranged between 29 and $82 \mathrm{mg} / \mathrm{l}$ while that of specific conductance ranged between 37 and $101 \mu \mathrm{S} / \mathrm{cm}$ (Table 3). Gathambara and Kanguo had the highest TDS while Gathanje, Kiongo and Rutara had the lowest. The reservoirs experienced a gradual increase in TDS and specific conductance after the dry season in the beginning of the year with peak levels occurring after the rain season in July. Thereafter, there was a consistent drop until the end of the year. The TDS and conductance results in all the reservoirs did not show any consistent vertical and longitudinal profiles, which indicated that chemo-stratification, was either very rare or non-existent as reflected also in the $\mathrm{pH}$.

Table 3: A summary of seasonal TDS and specific conductance in the reservoirs

(a) TDS (mg/l)

\begin{tabular}{lllllllll}
\hline Reservoir & Feb & Mar & Jun & Jul & Sep & Oct & Dec & Mean \\
Muruaki & 48.3 & 56.4 & 61.3 & 61.1 & 54.7 & 58.8 & 61.9 & 57 \\
Kahuru & 54.4 & 56.7 & 56.3 & 59.2 & 44.7 & 56.9 & 56.2 & 53.2 \\
Murungaru & 61.7 & 49.3 & 52.6 & 61.1 & 60.1 & 58.7 & 60.8 & 56.9 \\
Kanguo & 72.3 & 89.6 & 54.2 & 94.5 & 60.8 & 58.5 & 45.7 & 69.1 \\
Gathanje & 28.3 & 28.1 & 34.1 & 27.9 & 40.8 & 31 & 25.6 & 29.2 \\
Kiongo & 43.6 & 50.5 & 40.5 & 41.5 & 46.6 & 35.4 & 33.3 & 40.8 \\
Rutara & 53 & 55.4 & 50.8 & 58.5 & 52.4 & 52.4 & 46.1 & 51.8 \\
Gathambara & 29.5 & 55 & 66.1 & 101 & 67.4 & 125 & 101 & 82.3 \\
Mean & 48.9 & 55.1 & 49.8 & 65.2 & 52.4 & 60.5 & 53.8 & - \\
\hline
\end{tabular}


Some Aspects of Water Quality Characteristics in Small Shallow Tropical Man-Made Reservoirs in Kenya

(b) Specific Conductance $(\mu \mathrm{S} / \mathrm{cm})$

\begin{tabular}{lcccccccc}
\hline Reservoir & Feb & Mar & Jun & Jul & Sep & Oct & Dec & Mean \\
Muruaki & 62.5 & 77.8 & 81.7 & 76.4 & 74.1 & 77.9 & 80 & 75.5 \\
Kahuru & 80.7 & 80.7 & 69.6 & 77.1 & 61.1 & 75.6 & 62.5 & 70.9 \\
Murungaru & 87.3 & 65 & 59.1 & 75.3 & 85.4 & 76.8 & 69.2 & 73.2 \\
Kanguo & 134 & 106 & 137 & 72.5 & 87.3 & 55.7 & 107 & 101.9 \\
Gathanje & 39.2 & 39.7 & 46.5 & 38.3 & 55 & 31.5 & 28.7 & 37.3 \\
Kiongo & 57.5 & 81.9 & 48.8 & 53.8 & 63.4 & 40 & 43.1 & 54.2 \\
Rutara & 70.1 & 75.6 & 71.3 & 77.1 & 71.7 & 70.4 & 56.3 & 68.8 \\
Gathambara & 188 & 228 & 127 & 144 & 127 & 204 & 140 & 180.8 \\
Mean & 89.8 & 94.4 & 73.7 & 77.3 & 72.7 & 80.3 & 73.4 & - \\
\hline
\end{tabular}

The overall mean dissolved oxygen (DO) in the reservoirs ranged from 2.0 to $7.2 \mathrm{mg} / \mathrm{l}$ and the percentage oxygen saturation (POS) from 23.4 to $33.6 \%$ (Table 4). Most of the higher elevation plateau reservoirs had higher DO content than the rest of the reservoirs. The most aerated waterbodies included Kiongo and Gathanje where the DO content was above $4 \mathrm{mg} / \mathrm{l}$ almost throughout the year. Kiongo Reservoir was one of the most well aerated water bodies and maintained DO levels well above $4 \mathrm{mg} / \mathrm{l}$ despite its endorheic nature. This was probably sustained through high photosynthetic activity by both algae and submerged macrophytes, which are known to improve the DO content in reservoirs. The presence of submersed Ceratophyllum demersum in the reservoir was a good account for this situation. Figure 2 shows the vertical profiles of DO in the reservoirs. The levels of DO were lower in February and July probably because of limited turbulence in the dry season, and the prevalence of low atmospheric temperatures, respectively. In the dry season, the content of bottom DO was less than $4 \mathrm{mg} / \mathrm{l}$ in Kanguo, which was an indication of hypolimnial oxygen deficits.

Table 4: A summary of reservoir DO and POS

(a) DO $(\mathrm{mg} / \mathrm{l})$

\begin{tabular}{lllllllll}
\hline Reservoir & Feb & Mar & Jun & Jul & Sep & Oct & Dec & Mean \\
Muruaki & 4.3 & 8.8 & 7.7 & 4.4 & 6.7 & 6.7 & 6.0 & 6.7 \\
Kahuru & 2.6 & 7.1 & 6.6 & 4.0 & 7.4 & 6.3 & 5.7 & 5.9 \\
Murungaru & 4.0 & 6.7 & 7.8 & 4.1 & 6.8 & 6.4 & 5.3 & 6.1 \\
Kanguo & 2.9 & 6.0 & 5.8 & 3.6 & 5.9 & 5.9 & 6.5 & 5.1 \\
Gathanje & 4.9 & 4.9 & 7.2 & 2.3 & 5.9 & 6.8 & 6.5 & 5.2 \\
Kiongo & 7.8 & 5.3 & 8.3 & 1.5 & 6.7 & 8.0 & 9.9 & 6.8 \\
Rutara & 3.2 & 2.6 & 6.0 & 3.4 & 5.7 & 6.7 & 6.0 & 4.8 \\
Gathambara & 3.2 & 2.4 & 5.3 & 2.1 & 5.0 & 5.3 & 4.0 & 3.4 \\
Mean & 4.1 & 5.5 & 7.2 & 2.0 & 6.6 & 6.7 & 6.2 & - \\
\hline
\end{tabular}

(b) $\operatorname{POS}(\%)$

\begin{tabular}{lllllllll}
\hline Reservoir & Feb & Mar & Jun & Jul & Sep & Oct & Dec & Mean \\
Muruaki & 10.6 & 15.9 & 14.0 & 22.8 & 42.5 & 26.1 & 12.3 & 13.3 \\
Kahuru & 6.0 & 13.8 & 13.1 & 22.4 & 42.5 & 25.7 & 12.4 & 12.4 \\
Murungaru & 10.8 & 13.5 & 17.1 & 21.8 & 41.5 & 25.1 & 11.3 & 11.3 \\
Kanguo & 34.6 & 13.1 & 12.3 & 25.4 & 45.1 & 28.7 & 13.3 & 18.4 \\
Gathanje & 39.2 & 39.7 & 46.5 & 38.3 & 54.5 & 31.5 & 28.7 & 37.3 \\
Kiongo & 57.5 & 81.9 & 48.8 & 53.8 & 70.0 & 40.0 & 43.1 & 54.2 \\
Rutara & 70.1 & 75.6 & 47.1 & 50.6 & 71.7 & 70.4 & 56.3 & 68.8 \\
Gathambara & 7.6 & 15.3 & 17.8 & 4.8 & - & 13.8 & 9.8 & 10.3 \\
Mean & 29.6 & 33.6 & 25.3 & 32.3 & 46.6 & 38.9 & 23.4 & - \\
\hline
\end{tabular}

The results of oxidation reduction (redox) potential (ORPEh) measurements showed that reservoirs were mostly characterized by negative ORP- $\mathrm{E}_{\mathrm{h}}$ except during the onset of the long rains in March (Table 5). The only three reservoirs, which occasionally had positive ORP-Eh, were Kahuru, Murungaru and Gathambara. They also manifested lower levels of oxygen concentration and saturation (Table 4). Figure 3 shows the spatio-temporal

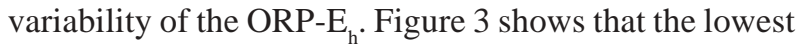
ORP- $\mathrm{E}_{\mathrm{h}}$ occurred in June and July after the rains, which was coupled by high DO concentration and saturation. From the results it was clear that the DO in the reservoirs was heavily utilized during the rains probably as a result of increased oxidation arising from the decomposition of incoming allochthonous matter.

Table 5: A summary of reservoir oxidation reduction potential $(\mathrm{mV})$

\begin{tabular}{lcccccccc}
\hline Reservoir & Feb & Mar & Jun & Jul & Sep & Oct & Dec & Mean \\
Muruaki & -4.1 & 8.3 & -45.9 & -27.5 & -50.5 & -15.3 & -12.6 & -16.7 \\
Kahuru & 3.8 & 127 & -9.4 & -28.5 & 19.6 & 9.4 & -20.3 & 32.6 \\
Murungaru & -7.3 & 106 & -74.9 & -14 & 8.5 & -18 & -0.1 & 10.3 \\
Kanguo & -2.6 & 11.8 & -60.6 & -99.5 & -17.5 & -22 & -23.2 & -41.6 \\
Gathanje & 1.4 & 47.1 & -47.6 & -13.6 & -11.2 & -43 & -42.3 & -29 \\
Kiongo & -102 & -26.5 & -42.3 & -53.3 & -31.9 & -60.6 & -93.3 & -70.4 \\
Rutara & -19.8 & 91.7 & -26.9 & -26.5 & -40.5 & -14.8 & -121 & -14.7 \\
Gathambara & 19.5 & 51.7 & 12.4 & -26.9 & 6.6 & 50.3 & 2.5 & 63.8 \\
Mean & -24.9 & 65.1 & -39.1 & -38.3 & 6.6 & -13.9 & -58.8 & - \\
\hline
\end{tabular}



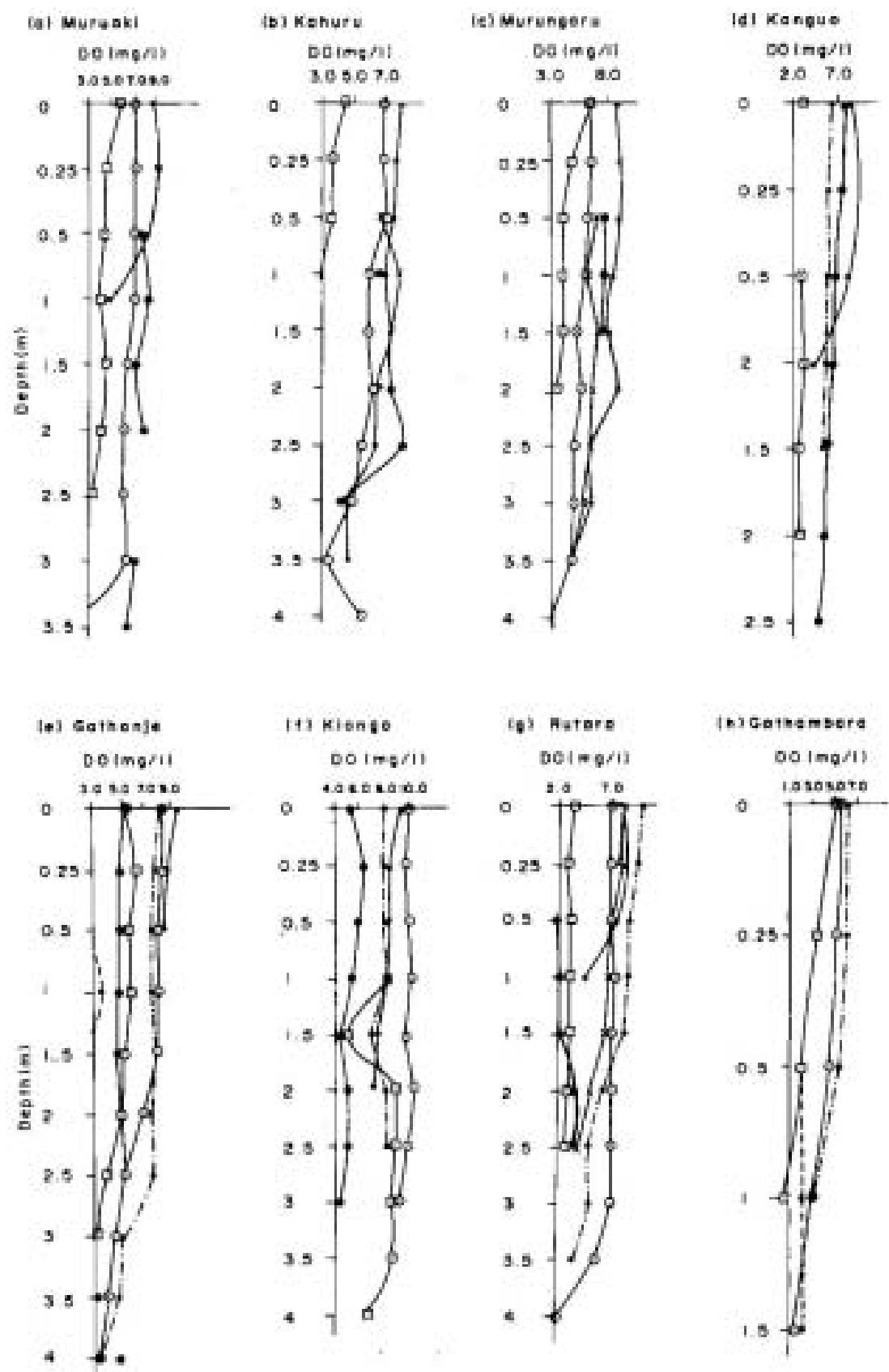
(8) Fatare
$00(\pi, 1)$
(b) Gothamserd

DO $1 m: / 11$
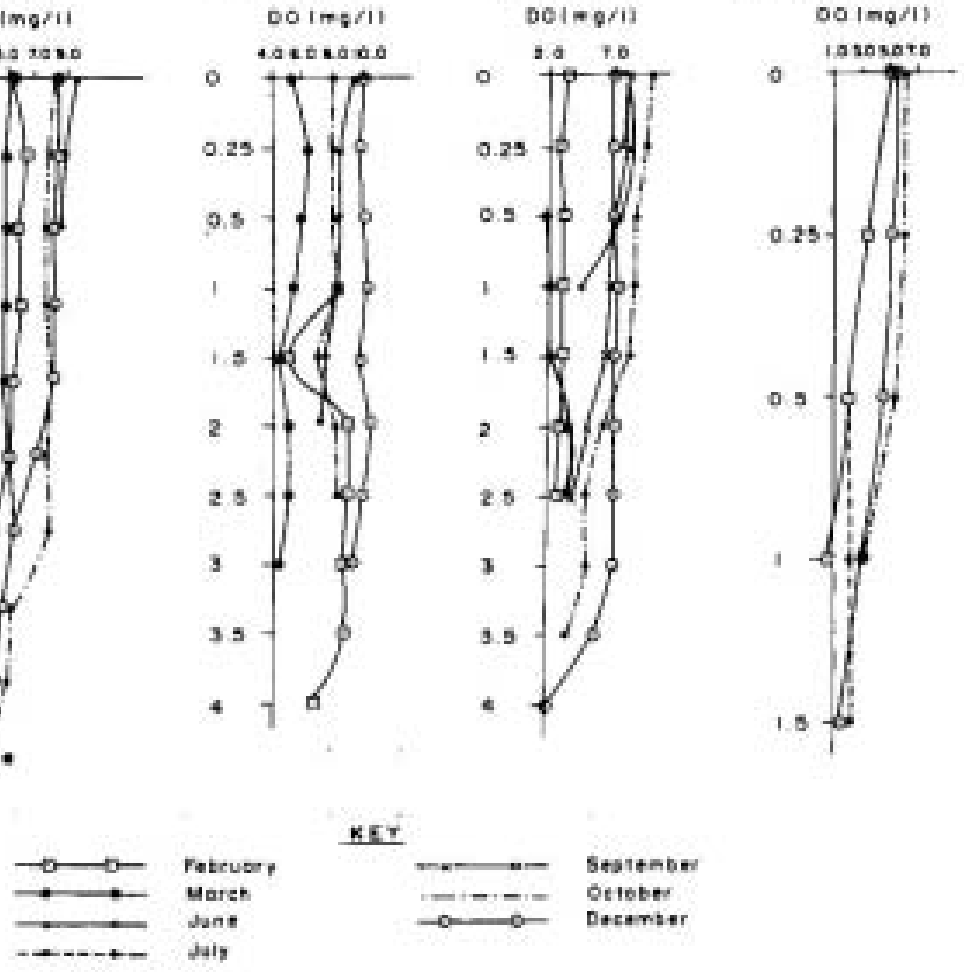

Figure 2: The spatio-temporal variability in reservoir dissolved oxygen 
(a) Spatial ORP

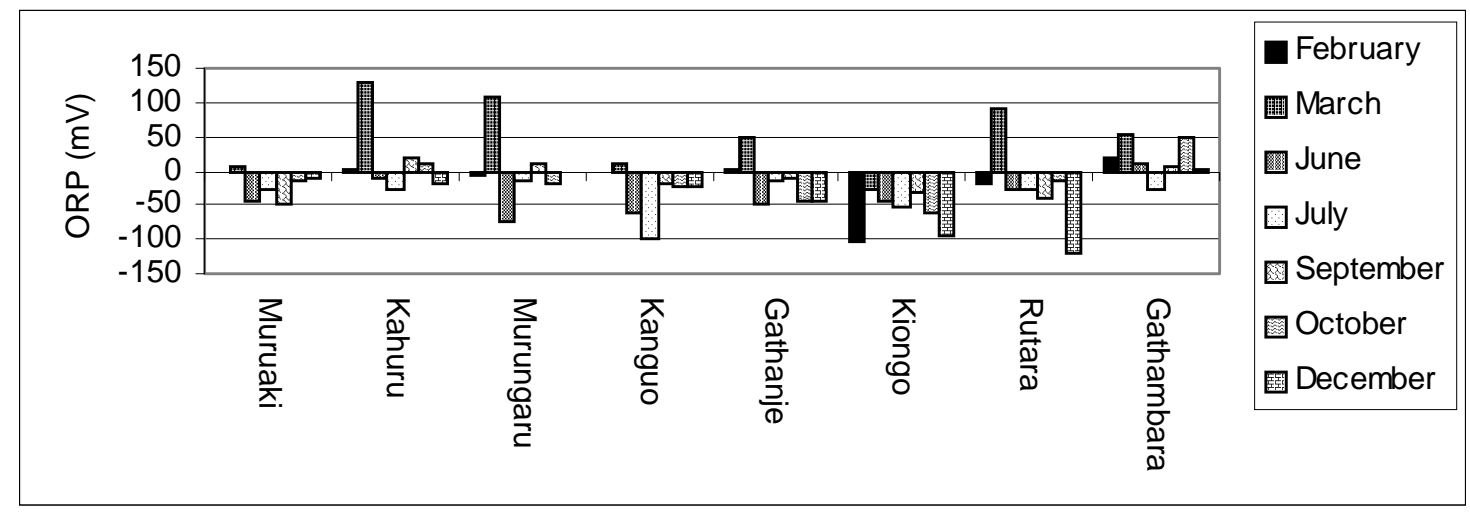

(b) Temporal ORP

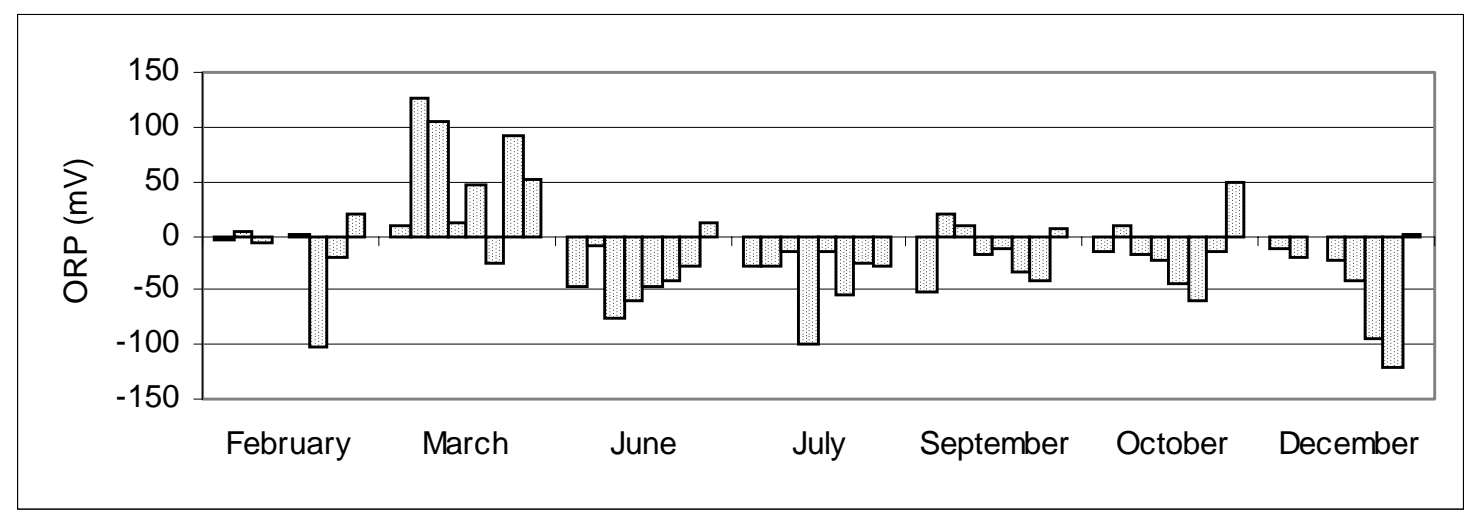

Figure 3: Seasonal profiles for reservoir dissolved oxygen

\section{DISCUSSION}

The water quality assessment showed the existence of slightly alkaline water $\mathrm{pH}$ in the reservoirs which is quite similar to other reservoirs in different parts of the world including Bangladesh (Haldar et al. 1992), Sri Lanka (de Silva 1988), Thailand (Duangasawasdi 1992), and even in North America (Moehl \& Davies 1993). Thornton (1980) recorded water $\mathrm{pH}$ in the range of $6.4-9.1$ within three Zimbabwean reservoirs. And in Masinga reservoir along the Tana River in Kenya, the $\mathrm{pH}$ is reported to fluctuate between 6 and 8.5 (Pacini, 1994). According to Moehl and Davies (1993) the typical $\mathrm{pH}$ range in reservoirs is usually 5-10 although significant short-term variations can occur due to changes in photosynthetic intensity. The inconsistent vertical pattern of $\mathrm{pH}$ in the study reservoirs indicated that chemical stratification was quite rare due to shallow depths and turbulent upwelling, which enabled water mixing almost throughout the year.
The $\mathrm{pH}$, which was mostly below 8 implied that the possibility of carbon limitation to phytoplankton growth is rare in the reservoirs. According to Goldman and Horne (1983), low $\mathrm{pH}$ at $<5.0$ can severely reduce aquatic species diversity. Other scientists indicate that persistent $\mathrm{pH}$ between 4.0 and 6.0 caused reproduction inhibition in fish (Boyd and Lichtkopper 1979, cited in de Silva 1992). The range of water $\mathrm{pH}$ in the study reservoirs was reasonably good for fish based on comparisons with literature from other areas (Goldman and Horne 1983, Taub 1996).

The higher water $\mathrm{pH}$ in Kiongo Reservoir ( $\mathrm{pH} 7.8$ ), which was located close to low water $\mathrm{pH}$ reservoirs, namely Rutara and Gathanje probably occurred due to the flushing effect from the market centre. The endorheic reservoir appeared to be mainly sustained by in-seepage. According to Hunt et al. (1999) the amount of ions carried by ground water through in-seepage is typically much higher than surface water and could have a profound influence on water $\mathrm{pH}$. The location 
of the reservoir just next to the rapidly growing Gwa-Kiongo market centre could also potentially influence the water quality due to the direct disposal of untreated domestic sewage into the reservoir.

The high $\mathrm{pH}$ recorded in Kanguo could be associated to the Sodic Phaeozems in the soil as well as the presence of lacustrine sediments in the area. This implies that Lake Ol Bolossat, which is in close proximity, was probably more extensive in the past similar to other rift lakes, and the reservoir and probably parts of its catchment are now lying on a former lake-bed. The available records indicate that most of the Rift Valley lakes are declining in size and becoming progressively alkaline (Mwaura,1992, Murimi 2000). The presence of lacustrine sediments in the vicinity of Kanguo can transform water $\mathrm{pH}$ towards the alkaline range.

The range of TDS and specific conductance in the reservoirs was quite low compared to other reservoirs in Kenya. The average conductivity in Masinga Reservoir which is one of the largest in Kenya with a surface area of $125 \mathrm{~km}^{2}$, ranges between 104 and $140 \mu \mathrm{S} / \mathrm{cm}$ (Pacini 1994). This is much higher than the levels recorded for small reservoirs in this study. But some small water bodies in Kenya are also known to have very high conductivity. Maithya (1998) for example recorded $670 \mu \mathrm{S} / \mathrm{cm}$ at Tinga Dam near Lake Victoria. The differences are probably associated with environmental factors such as catchment geology and vegetation cover, climate and runoff quality. The influence of landuse also varies from one area to another.

The range of TDS within the Kinangop reservoirs considered in this study was between 40 and $60 \mathrm{mg} / \mathrm{l}$. Previous measurements by Gaudet and Melack (1981) reported a mean of $91 \mathrm{mg} / \mathrm{l}$ in the Lower Malewa River. Therefore, our measurements were slightly lower, the difference probably emanating from the hydrographic contrast between fast running and slow flowing, partially stagnant water. The Malewa floodplain area within which Gaudet and Melack (1981) sampled is also situated in a much hotter and drier area probably with higher evaporative concentration effect.

The range of TDS and specific conductance at Kanguo at 40-100 mg/l and 50-140 $\mu \mathrm{S} / \mathrm{cm}$, respectively was quite high when compared to other plateau reservoirs in the study area. There are a number of reasons for this condition. Firstly, and as explained for water $\mathrm{pH}$ above, the location of the reservoir only about $3 \mathrm{~km}$ to the south of Lake $\mathrm{Ol}$ Bolossat means that the reservoir is probably lying on the bed of a former lake which was much bigger in size.
The high levels may therefore emanate from the strong influence of ancient lacustrine sediments.

Secondly, is the possibility of significant in-seepage from Lake Ol Bolossat as reflected by the remarkable stability in reservoir hydroperiod. The area is a hydrological crossborder zone between the Rift Valley basins of Lake Naivasha, Lake Elementaita and Ewaso Ng'iro River Basin. The contour maps for the area show that the altitude difference between Lake Ol Bolossat and Kanguo Reservoir is probably less than $15 \mathrm{~m}$. It therefore appears that a future hydrological linkage between Ewaso Nyiro and Lake Naivasha basins is likely. If this connection is eventually established through river capture, Lake Ol Bolossat which is mainly fed by streams and springs from the Sattima and Ndunduri ridges could supply water directly to Lake Naivasha through the Malewa River as shown in Figure 4.

The third reason for high TDS and conductivity in Kanguo is the soil which is dominated by Sodic Phaeozems which have been greatly modified after many years of large scale mechanized farming involving intense agro-chemical application. The strong human influence around the reservoir has also replaced the natural vegetation with a wide range of eucalypts and this could affect ion balance due to increased desiccation.

The lowered water $\mathrm{pH}$ and TDS in Gathanje and Rutara probably indicated the strong buffering effect by both catchment vegetation and riparian macrophytes against material import especially soil. The two reservoirs had substantial riparian vegetation cover than the rest of the study reservoirs. There was also slightly lowered TDS and conductivity at Kiongo reservoir, which probably occurred due to the lack of consistent outflow. The restricted catchment for this reservoir means that ion concentration cannot be very high because the influence of catchment geology is minimal. However, the reservoir receives substantial amounts of untreated domestic effluent from the nearby Gwa-Kiongo market centre. This market centre may eventually exert a very strong influence on the water quality of the reservoir in the future unless the sewage and solid wastes are treated or diverted away from the water body. If this is not done the water quality in the reservoirs may eventually threaten the lives of the local community including a secondary school who tap water directly from the reservoir.

Thornton (1986) examined the water quality in some 103 natural African lakes including 64 reservoirs and found the overall conductivity range in the latter to be $10-800$ $\mu \mathrm{S} / \mathrm{cm}$. The specific conductance values recorded here were also slightly lower than those reported for some Asian 


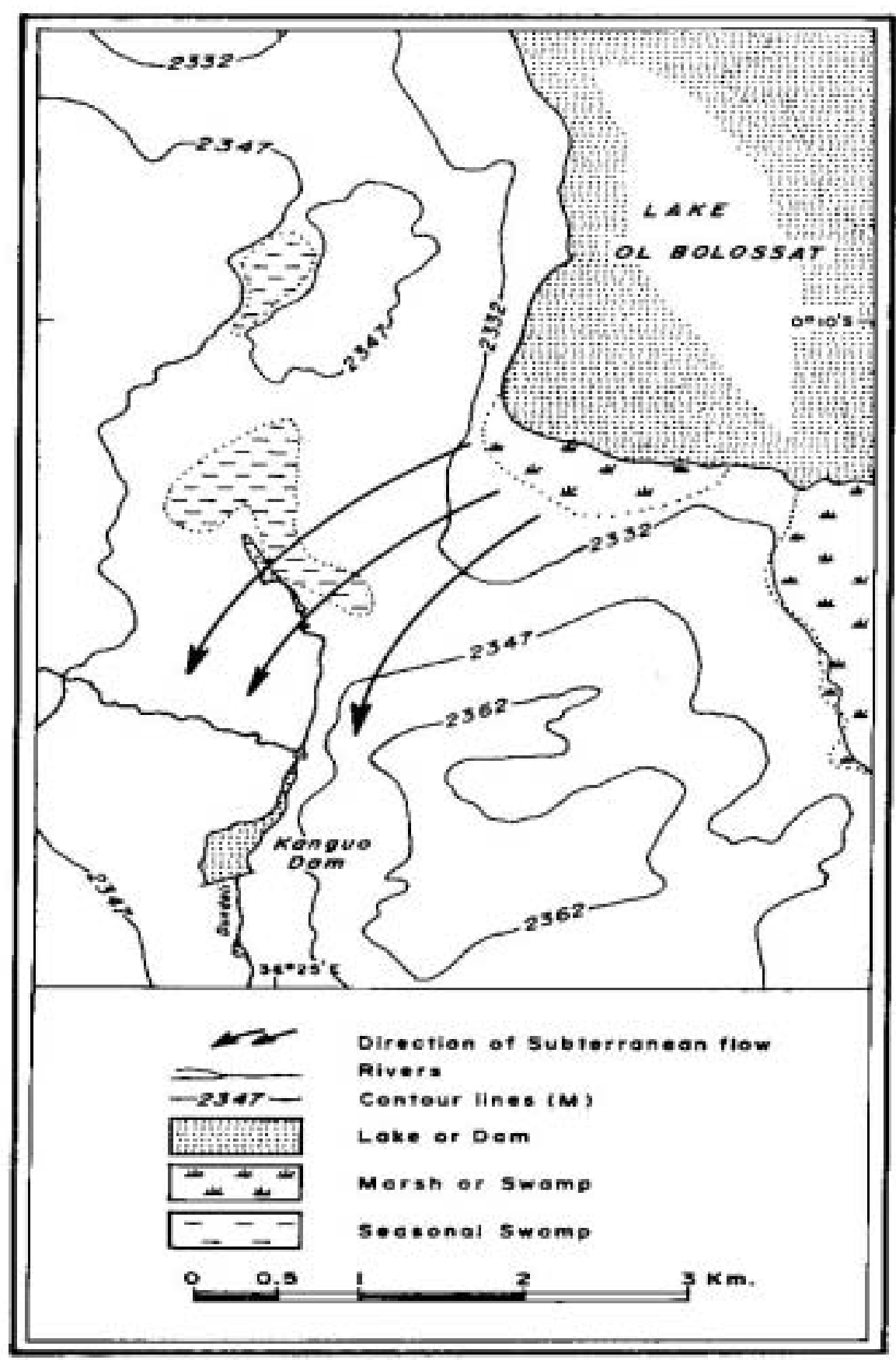

Figure 4: The suspected hydrological linkage between Lake Ol Bolossat and the Kanguo Reservoir (Mwaura 2004) 
reservoirs (de Silva 1988, Screenivasan 1992) and some of the large man-made lakes in Africa such as Lake Nasser (Crul and Roest 1995) but quite similar to those of some large reservoirs such as Lake Volta (Crul and Roest 1995). This could be attributed to differences in reservoir morphometry and catchment environment especially landscape, climate, geology, soils, vegetation and landuse. Table 6 shows a comparison of electrical conductivity in reservoirs of similar morhometry in Kenya, Zimbabwe and South Africa. The mean conductivity is highest in South Africa and lowest in Zimbabwe. Kenya is in the middle but more closer to Zimbabwe for both small and medium reservoirs.

The average concentration of DO in the reservoirs (2-10 $\mathrm{mg} / \mathrm{l}$ ) was slightly lower than the levels in large and deeper reservoirs such as the Masinga reservoir (0.2-10.3 mg/l, Pacini 1994). But the DO concentration in the Naivasha basin lakes was quite similar to the levels in the reservoirs. Brierley et al. (1987) recorded $6.9 \mathrm{mg} / \mathrm{l}$ in the Naivasha Main Lake and 7.1 mgO2/l in the Oloidien Bay near the Ol Kalia Gorge. However, some tropical waterbodies have recorded much lower oxygen levels. Howard-Williams et al. (1989), for example recorded very low DO levels (0.3 to 5.1 $\mathrm{mgO}_{2} / \mathrm{l}$ ) within a shallow floodplain oxbow lake in Sao Paulo, Brazil.

The level of dissolved oxygen at the shallow Gathambara Reservoir was very low and the reservoir was almost consistently anoxic and almost bordering on the critical point of tolerance by lifeforms due to the accumulation of sediment and allochthonous matter. During the dry season, the reservoir emitted foul smell probably due to the production of hydrogen sulphide or methane from the huge layer of organic sludge. The study on Lake Kariba by Balon and Coche (1974) concluded that the flushing of allochthonous organic matter increases biochemical demand and can reduce oxygen concentration below critical levels.

The range of vertical $\Delta \mathrm{DO}$ in the study reservoirs was lower than the range for similar reservoirs in India (Sreenivasan 1992). The hypolimnial oxygen deficit which occurred in some of the reservoirs has also been reported elsewhere including, in Kenya (Pacini 1994) and Southern Africa (Thornton 1987b). Previously, hypolimnial oxygen deficits were considered to indicate productive waters (Thieneman 1928, de Silva, 1992). But Mitchell and Marshall (1974) and Walmley and Toerin (1977) are cited by Thornton (1987b) cautioning about tropical hypolimnetic deoxygenation which could occur regardless of trophic status because it is more directly influenced by seasonal weather changes especially in terms of rainfall, temperature and wind. In Masinga Reservoir, Kenya, Pacini (1994) suggests that hypolimnetic oxygen depletion increases during the rain season because large amounts of fresh oxidizable matter are washed into the reservoir and settling at the bottom. Balon and Coche (1974) have also suggested the same occurrence in for Lake Kariba.

Table 6: Electrical conductivity levels in some reservoirs

\begin{tabular}{lll}
\hline Country/Reservoir & $\begin{array}{l}\text { Area } \\
\left(\mathrm{km}^{2}\right)\end{array}$ & $\begin{array}{l}\text { Conductivity } \\
(\mu \mathrm{S} / \mathrm{cm})\end{array}$ \\
\hline
\end{tabular}

$\begin{array}{lll}\text { KENYA } & & \\ \text { Muruaki } & 0.1 & 76 \\ \text { Kahuru } & 0.09 & 71 \\ \text { Murungaru } & 0.1 & 73 \\ \text { Kanguo } & 0.1 & 102 \\ \text { Gathanje } & 0.1 & 37 \\ \text { Kiongo } & 0.2 & 54 \\ \text { Rutara } & 0.07 & 69 \\ \text { Gathambara } & 0.06 & 181 \\ \text { Mean } & 0.1 & 83\end{array}$

ZIMBAB WE(Thornton 1987a)

$\begin{array}{lll}\text { Cleveland } & 0.3 & 72 \\ \text { Connemara } & 0.4 & 11 \\ \text { Gulliver } & 0.1 & 9 \\ \text { Mare } & 0.1 & 10 \\ \text { Pudon } & 0.1 & 16 \\ \text { Rhodes } & 0.1 & 19 \\ \text { Savory } & 0.1 & 300 \\ \text { Udu Valley } & 0.1 & 40 \\ \text { Mean } & 0.2 & 60\end{array}$

SOUTH AFRICA (Thornton 1987a)

\begin{tabular}{lll} 
Henley & 0.7 & 68 \\
Nahoon & 0.8 & 580 \\
Tonteldoos & 0.04 & 128 \\
Vernon Hooper & 0.8 & 277 \\
Mean & 0.6 & 263 \\
\hline
\end{tabular}

in Kenya, Zimbabwe and South Africa

The DO conditions in lakes and reservoirs have an important implication on aquatic lifeforms including fish. Generally, fish movements are constrained by lower oxygen content because fish prefer well-oxygenated water (Boyd and Lichtkopper 1979, Goldman and Horne 1983, Taub 1996). The results of DO analysis in this study however indicated that the potential for fishery development was quite promising in both Gathanje and Kiongo where the mean DO content was 5.2 and $6.8 \mathrm{mg} / \mathrm{l}$ respectively and the water bodies were 
quite transparent. Gathanje reservoir was found to support a fairly reliable fishery community composed of tilapia (Tilapia Spp.), common carp (Cyprinus carpio) and crayfish (Procambarus clarkii).

The fact that redox potential was generally low in the study reservoirs almost throughout the year means that low oxygen concentration and anoxia can be quite common particularly in the hypolimnia and botom sediments. Oxygen is generally absent from sediments when $\mathrm{E}_{\mathrm{h}}$ reaches +400 or lower (Spenser \& Ksander 1997). This condition has a strong implication on reservoir nutrients because anoxia or complete deoxygenating of the hypolimnion may return large amounts of phosphorus to the water column from the bottom sediments.

The results of this study demonstrated the water quality impacts of an upstream reservoir on a downstream one. The results showed tremendous water quality contrast between Muruaki Reservoir and Kahuru Reservoir located $3 \mathrm{~km}$ apart along the Magutu River with the former in the upstream and the latter in the downstream. There was $14 \%$ improvement in water transparency at Kahuru, which showed that the upstream impoundment operated as a natural sink for suspended matter thereby lowering the levels of water $\mathrm{pH}$, TDS and electrical conductivity (Table 7). The net decline in the level of DO was probably attributed to reservoir morphometric differences because Kahuru was a much bigger and deeper water body (Table 1).

Table 7: A comparison of physico-chemical characteristics between Muruaki reservoir (upstream) and Kahuru reservoir (downstream)

\begin{tabular}{llll}
\hline Parameter & Muruaki & Kahuru & Net Change \\
Water transparency $(\mathrm{m})$ & 0.28 & 0.32 & ${ }^{+} 0.04$ \\
ORP $(\mathrm{mV})$ & -16.7 & 32.6 & ${ }^{+} 15.9$ \\
Water pH & 7.9 & 7.2 & -0.70 \\
TDS (mg/l) & 57.0 & 53.2 & -3.80 \\
Specific conductance & 75.5 & 70.9 & -4.60 \\
$(\mu \mathrm{S} / \mathrm{cm})$ & & & \\
DO $(\mathrm{mg} / \mathrm{l})$ & 6.7 & 5.9 & -0.80 \\
POS $(\%)$ & 13.3 & 12.4 & -0.90 \\
\hline
\end{tabular}

\section{CONCLUSIONS}

Table 8 gives a summary of the water quality conditions in the plateau and escarpment reservoirs. The summary results showed a clear difference in water quality between the plateau and escarpment reservoirs in the study area. The water transparency increased by approximately 40 $\mathrm{cm}$ from the high elevation headwater plateau reservoirs to the slightly lower elevation middle catchment escarpment reservoirs. The water $\mathrm{pH}$, TDS and DO declined slightly from the plateau reservoirs to the escarpment reservoirs. The results clearly implied that headwater reservoirs will not necessarily have more clear and transparent water because of their upstream location. It appears that reservoir water quality is probably driven more by type of landscape, catchment geology, landcover and landuse.

Table 8: A summary of water quality characteristics in plateau and escarpment reservoirs

\begin{tabular}{|l|c|c|c|c|l|}
\hline $\begin{array}{l}\text { Water } \\
\text { quality } \\
\text { attribute }\end{array}$ & $\begin{array}{l}\text { O verall } \\
\text { mean }\end{array}$ & Plateau & Escarpment & $\begin{array}{l}\text { Net } \\
\text { change }\end{array}$ & $\begin{array}{l}\text { KBS } \\
\text { (Drinking } \\
\text { water) }\end{array}$ \\
\hline $\begin{array}{l}\text { Water } \\
\text { transparency } \\
(\mathrm{m})\end{array}$ & 0.45 & 0.28 & 0.63 & ${ }^{+} 0.4$ & - \\
\hline Water $\mathrm{pH}$ & 7.5 & 7.6 & 7.3 & -0.3 & $6.5-8.5$ \\
\hline $\mathrm{TDS}\left(\mathrm{mg}^{\prime} \mathrm{l}\right)$ & 55 & 59 & 52 & -7 & 1000 \\
\hline $\mathrm{DO}\left(\mathrm{mgO}_{2} . \mathrm{l}\right)$ & 5.5 & 6 & 5.1 & -0.9 & - \\
\hline
\end{tabular}

The water quality in the reservoirs was found to be suitable for domestic and livestock utilization in accordance to the Kenya Bureau of Standards (KBS, 1996) benchmarks for water $\mathrm{pH}$ and TDS (Table 8). However, additional water quality parameters are required to confirm this conclusion. The reservoirs were found to possess a good potential for fisheries development. The potential in Kenya is probably higher in Ecological Zones III and IV like the area considered in this study. Ecological Zones I and II would probably be too cold for the fish while Ecological Zones V, VI and VII would be highly vulnerable to periodic drying out of reservoirs.

The following considerations and adjustments could eventually improve the quality and quantity of reservoir resources, especially water, and minimise the risk of future disasters especially those of disease epidemics:

(a) Technical purification of water before use is immediately necessary in some reservoirs like Kiongo and Gathanje, which supply a large population including schools. Regular monitoring of the water quality in such waterbodies is imperative to avoid possible disasters of public health.

(b) Appropriate sewage treatment and disposal systems for existing and upcoming market centres like 
Gathanje and Kiongo which are, located close to water supply reservoirs in order to minimise reservoir water contamination. Contamination of water resources could also be minimised by digging pit latrines away from the waterways or using soak pits.

Several options are recommended for the long-term maintenance of high water quality and quantity standards in the reservoirs as follows:

(a) De-encroachment of waterways by creating sufficient riparian buffer zones along rivers and around reservoirs, which will improve storage and quality of water. The presence of riparian buffers will check and reduce movement of soil from land to the water, which should also cut down the loading of nutrients in the reservoirs. Such de-encroachment of waterways could be achieved through the new Environmental Management and Co-ordination Act of 2000, which disapproves any form of development within the critical water banks. But the success this could depend on the policy and legal mechanisms for the implementation of the Act.

(b) Restoration of degraded stream banks and the reservoir shore areas in order to rehabilitate lost waterways. One approach could involve the regeneration of macrophytes including their reintroduction. Some outstanding potential species for this process include Cyperus, Phragmites, Ceratophyllum, Potamogeton, Egeria and Hibiscus. Hibiscus canabinus or Kenaf, which is a tropical plant, is for example used for the phyto-remediation of water supply reservoirs in Japan. The introduction of macrophytes in degraded reservoirs could also improve aeration in hypolimnial oxygen deficient waterbodies, which could ultimately transform the biodiversity. However, the restoration of waterways through the introduction of non-native species will require sufficient research to avoid possible ecological disasters.

(c) Mechanical de-sedimentation of the highly silted reservoirs like Gathambara could ultimately be inevitable in order to maintain a good water supply in the rural areas. Although this could be an expensive venture it could greatly improve water quality by removing nutrients from their sinks in the bottom sediments.

(d) Good catchment management should be long-term effort towards good water quality. This could include improvement of soil and water management, restoration of degraded catchments through reforestation, and promotion of organic farming to reduce the leakage of agrochemical into the reservoirs.

The breaking of existing institutional, technical, and socioeconomic barriers which prevent the rural communities from achieving maximum benefit from small reservoirs could start by supporting people to secure full benefits from small reservoirs. This could, for example involve the multipurpose development of reservoirs through the promotion of sustainable community-based fisheries and ecotourism projects which require substantial effort for appropriate capacity building and installation of vital equipment and management skills. The escarpment reservoirs were, for example considered to be quite promising for future fisheries development. The only plateau reservoir, which could qualify among those under investigation, was Kanguo. But Gathanje, Kiongo and Rutara were also found to be particularly good for community-based fisheries and ecotourism development.

\section{ACKNOWLEDGEMENTS}

We are grateful to the German Academic Exchange Service (DAAD) and the Kenya Wildlife Service for supporting the study financially. We also appreciate the support of my friends Dr John Githaiga of University of Nairobi who assisted with good ideas and fieldwork and Dr. John Warui Kiringe of the School of Field Studies who read and commented on an earlier version of this paper.

\section{REFERENCES}

1. Balon, E.K. \& A.G. Coche (1974): Lake Kariba: A manmade tropical ecosystem in Central Africa. Dr. W-Junk. The Hague.

2. Brierley, B., Harper, D. and R.Thomas (1987): Water Chemistry and Phytoplankton Studies at Lake Naivasha - Short Term Spatial and Temporal Variations. University of Leicester Studies on the Lake Naivasha Ecosystem. Final Report to the Government of Kenya.

3. Brower J.E. \& J.H. Zar (1977): Field and laboratory methods for general ecology. Second Edition. WCB Publishers, Dubuque.

4. Central Bureau of Statistics, CBS (2003): Datasheets on population and development indicators from the 1999 Kenya population and housing census. CBS, Nairobi. 
5. Crul, R.C.M. \& F.C. Roest [eds.] (1995): Current status of fisheries and fish stocks of the four largest African reservoirs Kainji, Kariba, Nasser/Nubia and Volta. CIFA Technical Paper No. 30. FAO, Rome.

6. de Silva, S.S. (1988): Reservoirs of Sri Lanka and their fisheries. FAO Fisheries Technical Paper No. 298, Rome.

7. de Silva, S.S. (1992): Reservoir Fisheries of Asia. Proceedings of the 2nd Asian Reservoir Fisheries Workshop Held in Hangzhou, Peoples Republic of China, 1519 October, 1990. IDRC, Ontario.

8. Duangsawasdi, M. (1992): Postimpoundment studies on aquatic ecology and fisheries in Bhumibol and Sirikit Reservoirs, Thailand In de Silva: Reservoir Fisheries of Asia. Proceedings of the 2nd Asian Reservoir Fisheries Workshop Held in Hangzhou, Peoples Republic of China, 15 19 October 1990. IDRC, Ontario.

9. Gaudet, J.J. \& J.M. Melack (1981): major ion chemistry in a tropical African lake basin. Freshwater Biol. 11: 309333.

10. Goldman C.R. \& A.J.Horne (1983): Limnology. McGrawHill, Tokyo.

11. Haldar G.C, Mazid, M.A. and K.K. Ahmed (1992): Limnology and primary production of Kaptai Lake, Bangladesh. In: de Silva: Reservoir Fisheries of Asia. Proceedings of the 2nd Asian Reservoir Fisheries Workshop Held in Hangzhou, Peoples Republic of China, 1519 October 1990. IDRC, Ontario.

12. Howard-Williams, C., Esteves, F., Santos, J.E. \& M.T. Downes (1989): Short term nitrogen dynamics in a small Brazilian wetland (Lago Infernao, Sao Paulo). Journal of Tropical Ecology 5:323-335.

13. Hunt, R.J., Walker, J.F. \& D.P. Krabbenhoft (1999): Characterizing hydrology and the importance of groundwater discharge in natural and constructed wetlands. Wetlands 19(2):458-472.

14. ICOLD (1998): World Register of Dams. ICOLD, Paris.

15. Jones. J.R. \& M.F. Knowlton (1993): Limnology of Missouri reservoirs: An analysis of regional patterns. Lake and Reser. Manage. 8(1):17-30.
16. Kenya Bureau of Standards (1996): Kenya standard: Specification for drinking water:KS 05-459: PART 1 (ICS 13.060.20), KBS, Nairobi.

17. Maithya, J. (1998): A Survey of Ichthyofauna of Lake Kanyaboli and Other Small Waterbodies in Kenya. Alternative Refugia for Endangered Fish Species. Naga, The ICLARM Quarterly, and January-March: 54-56.

18. Marshall, B. and M. Maes [eds.] (1994): Small Water Bodies and their Fisheries in Southern Africa. CIFA Technical Paper No. 29. FAO, Rome.

19. Martins, O and W. Salomons (2002): Dissolved and Particulate Load of African Rivers - An Overview. In: Arthurton, R.S., Kremer, H.H.. Odada, E., Salomons, W. \& J.I.M. Crossland - African Basins: LOICZ global change assessment and synthesis of river catchmentcoastal sea interaction and human dimensions. LOICZ Reports \& Studies No. 25.Texel, the Netherlands.

20. McCall, G.J.H(1959): Geology of the Nakuru-Thompson Falls-Lake Hannington Area. Ministry of Natural resources. Geological Survey Report.

21. Meaden, G.J. and J.M. Kapetsky (1991): Geographical Information Systems and Remote Sensing in Inland Fisheries and Aquaculture. FAO Technical Paper No. 318, Rome.

22. Moehl, J.F. \& W.D. Davies (1993): Fishery intensification in small water bodies. A review for North America. FAO Fisheries Technical Paper No. 333, Rome.

23. Murimi, S.K. (2000): The drying up of East African Rift Valley Lakes in recent times with special reference to Lake Elementaita. In - Gichuki, F.N., Mungai, D.N., Gachene, C.K.K. and D.B. Thomas: Land and water management in Kenya - Proceedings of the $4^{\text {th }}$ national workshop, Wida Highway Motel, Kikuyu, Kenya.

24. Mwaura, F. (1992): Some aspects of hydrochemistry, lake level and vegetation dynamics in the Lake Elementaita drainage basin, Kenya. Unpublished M.Sc. thesis, University of Nairobi.

25. Mwaura, F (2004): Some aspects of the limnogeography of small high altitude tropical man-made reservoirs in the Eastern Rift Valley, Kenya. Unpublished Ph.D thesis, University of Nairobi. 
26. Naiman, R.J. \& H. Decamps [eds.] (1990): The Ecology and management of aquatic terrestrial ecotones. MAB Series Volume 4. UNESCO, Paris.

27. Pacini, N (1994): Coupling of land and water: phosphorus fluxes in the Upper Tana River Catchment, Kenya. Unpublished Doctor of Philosophy thesis, Leicester University.

28. Patten, D.T. (1998): Riparian ecosystems of semi-arid North America: Diversity and human impacts. Wetlands 18(4):498-512.

29. Pratt, D.J., Greenway, P.J. \& M.D. Gwynne (1966): A classification of East African Rangelands with an appendix on terminology. J. of Appl. Ecol. 3:309-382.

30. Spencer, D.F. and G.G. Ksander (1997): Influence of anoxia on sprouting of vegetative propagules of three species of aquatic plant propagules. Wetlands 17(1):55-64.

31. Sreenivasan, A. (1992): Limnology and fisheris of some south Indian reservoirs. In: de Silva, S.S. (1992): Reservoir Fisheries of Asia. Proceedings of the 2nd Asian Reservoir Fisheries Workshop Held in Hangzhou, Peoples Republic of China, 1519 October, 1990. IDRC, Ontario.

32. Taub, F.B. - Ed. (1996): Lakes and reservoirs Ecosystems of the world series number 23. Elsevier, Amsterdam.
33. Templer, P., Findlay, S. \& C. Wigand (1998): Sediment chemistry associated with native and non-native emergent macrophytes of a Hudson River marsh ecosystem. Wetlands 18(1):70-78.

34. Thienemann, A. (1928): Die Sauerstoff im eutrophen und oligotrophen ss. Springer Verlag, Berlin. Die Binnengewasser, Bd. IV, 1-175.

35. Thompson, A.O. (1962): Geology of the Kijabe area. Ministry of Natural Resources, Mines \& geological Department, Nairobi.

36. Thornton, J.A. (1980): A Comparison of the Summer Phosphorus Loadings to Three Zimbabwean WaterSupply Reservoirs of Varying Trophic States. Water SA 6(4) 163-170.

37. Thornton, J.A. (1987a): A Review of Some Unique Aspects of the Limnology of Shallow Southern African Man-made Lakes. Geojournal 14.3:339-352.

38. Thornton, J.A. (1987b): Aspects of Eutrophication Management in Tropical/Subtropical Regions. J. Limnol. Soc. Sth. Afr. 13(1):25-43.

39. Tilman, D., Kilham, S.S. \& P. Kilham (1982): Phytoplankton community ecology: The role of limiting nutrients. Ann. Rev. Ecol. Syst. 13:349-372.

40. WWF (1999): A place for dams in the 21st century? WWF, Gland. 